\title{
Lanfrediella amphicirrus gen. nov. sp. nov. Nematotaeniidae (Cestoda: Cyclophyllidea), a tapeworm parasite of Rhinella marina (Linnaeus, 1758) (Amphibia: Bufonidae)
}

\author{
Francisco Tiago de Vasconcelos Melo', Elane Guerreiro Giese', \\ Adriano Penha Furtado', Maurílio José Soares², Evonnildo Costa Gonçalves ${ }^{3}$, \\ Antonio Carlos Rosário Vallinoto ${ }^{4}$, Jeannie Nascimento dos Santos ${ }^{1 /+}$
}

\author{
${ }^{1}$ Laboratório de Biologia Celular e Helmintologia Profa. Dra. Reinalda Marisa Lanfredi ${ }^{3}$ Laboratório de Polimorfismo de DNA \\ ${ }^{4}$ Laboratório de Virologia, Instituto de Ciências Biológicas, Universidade Federal do Pará, Av. Augusto Correa s/n, 66075-900 Belém, PA, Brasil \\ ${ }^{2}$ Laboratório de Biologia Celular, Instituto Carlos Chagas-Fiocruz, Curitiba, PR, Brasil
}

The family Nematotaeniidae, tapeworms commonly found in the small intestines of amphibians and reptiles, includes 27 recognised species distributed among four genera: Bitegmen Jones, Cylindrotaenia Jewell, Distoichometra Dickey and Nematotaenia Lühe. The taxonomy of these cestodes is poorly defined, due in part to the difficulties of observing many anatomical traits. This study presents and describes a new genus and species of nematotaeniid parasite found in cane toads (Rhinella marina) from eastern Brazilian Amazonia. The cestodes were collected during the necropsy of 20 hosts captured in the urban area of Belém, Pará. The specimens were fixed and processed for light microscopy, scanning electron microscopy (SEM) and three-dimensional (3D) reconstruction. Samples were also collected for molecular analyses. The specimens presented a cylindrical body, two testes and paruterine organs. However, they could not be allocated to any of the four existing nematotaeniid genera due to the presence of two each of dorsal compact medullary testes, cirri, cirrus pouches, genital pores, ovaries and vitelline glands per mature segment. Lanfrediella amphicirrus gen. nov. sp. nov. is the first nematotaeniid studied using Historesin analysis, SEM and $3 D$ reconstruction, and it is the second taxon for which molecular data have been deposited in GenBank.

Key words: Cestoda - Nematotaeniidae - 3D reconstruction - Rhinella marina

Nematotaeniidae Lühe 1910 is a family of cyclophyllidean cestodes characterised by their small size, the presence of paruterine organs and a cylindrical body with external segmentation restricted to the terminal region of the body. They also have two compact testes, ovaries and vitellaria located in the medulla (Jewell 1916, Douglas 1958, Yamaguti 1959, Jones 1987).

Adult specimens of these worms are differentiated by a number of morphological traits that are of considerable importance for the diagnosis of genera and species, including the position and number of paruterine capsules, as well as the terminal genitalia morphology. Although the taxonomy of the group is unclear, due in part to the difficulties of observing some anatomical characteristics, Jones (1987) divided the nematotaeniids into four genera: the monospecifics Bitegmen Jones, 1987, and Distoichometra Dickey, 1921, Nematotaenia Lühe, 1910, with seven species, and Cylindrotaenia Jewell, 1916, with a total of 18 species.

Financial support: CAPES PROCAD/2005, PROCAD NF/2009, PROPESP/FADESP-UFPA

+ Corresponding author: jeannie@ufpa.br

Received 24 January 2011

Accepted 6 June 2011
Nematotaeniids are found in the small intestines of reptiles and amphibians, such as the cane toad Rhinella marina (syn. Bufo marinus) (Linnaeus, 1758). The natural range of $R$. marina extends from southern Texas to central Brazil, although the species has also been introduced in Florida, a number of Caribbean and Pacific islands, New Guinea and northeastern Australia (Barton 1997). The known helminth parasites of this species include 55 nematodes, 41 digenea, eight cestodes, one monogenea and an acanthocephalan (Espinoza-Jiménez et al. 2007, Espínola-Novelo \& Guillén-Hernandez 2008, Santos et al. 2008, 2011).

The present study identified and describes a new nematotaeniid parasite of $R$. marina from eastern Brazilian Amazonia. This nematotaeniid represents a new genus and the diagnosis of the new taxon was based in part on analysis of the scolex and segments using scanning electron microscopy (SEM), three-dimensional (3D) reconstruction and histology. The description of the new taxon is also supported by molecular data.

\section{MATERIALS AND METHODS}

A total of $20 R$. marina toads were collected from urban areas of Belém, state of Pará (PA), Brazil, between October 2007-September 2008. The cestodes found in each specimen were fixed in $2 \%$ glacial acetic acid and $3 \%$ formaldehyde in $95 \%$ ethanol for analysis using both light microscopy and SEM. Some of the specimens were fixed with $2.5 \%$ glutaraldehyde in $0.1 \mathrm{M}$ sodium cacody- 
late buffer $(\mathrm{pH}$ 7.2) and then embedded in paraffin and hydroxyethyl methacrylate resin (Leica Historesin Embedding Kit) for histological analysis.

The cestodes were stained with carmin, dehydrated in ethanol, cleared in methyl salicylate and mounted on glass slides with Entellan. Illustrations were made with the aid of a camera lucida linked to an Olympus BX41 microscope. All measurements, means and standard deviations are given in micrometers unless otherwise indicated, and the ranges are given in parentheses.

Mature segments were embedded in paraffin and sectioned transversely into $8 \mu \mathrm{m}$-thick serial sections, which were then stained with hematoxylin-eosin. Serial, $3 \mu \mathrm{m}$-thick, transversal and longitudinal sections of specimens embedded in Historesin were stained with $1 \%$ toluidine blue and used in the morphometric analyses.

Specimens prepared for SEM were post-fixed in 1\% $\mathrm{OsO}_{4}$ dehydrated, mounted on stubs, sputter-coated with gold and examined using a JEOL 5310 microscope.

For the 3D reconstructions, serial longitudinal sections of Historesin-embedded samples of strobilae were photographed. The alignments and 3D reconstructions were conducted using the RECONSTRUCT ${ }^{\mathrm{TM}}$ software. Images from stained and cleared specimens were captured on different focal planes using a Nikon Eclipse E600 microscope equipped with differential interference contrast and a single image with the best-adjusted focus was obtained using the CombineZP software.

Genomic DNA (gDNA) was obtained from whole worms using the ChargeSwitch gDNA Mini Tissue Kit (Invitrogen Life Technologies, Gaithersburg, MD, USA). The $18 \mathrm{~S}$ small subunit ribosomal RNA (18S rRNA) gene was partially amplified via polymerase chain reaction (PCR) in two overlapping fragments using the primers Ces1/Ces2 and 2880/B and following the procedure of Skeriková et al. (2001). The PCRs were performed in $25 \mu \mathrm{L}$ final volume, containing 5-10 ng of DNA, $50 \mathrm{mM} \mathrm{KCl}, 2 \mathrm{mM} \mathrm{MgCl}, 10 \mathrm{mM}$ Tris- $\mathrm{HCl}$, $50 \mu \mathrm{M}$ of each dNTP, $0.5 \mu \mathrm{M}$ of each oligonucleotide and one unit of Taq DNA polymerase (Invitrogen). Reactions containing the Ces1/Ces 2 primers were denatured for $4 \mathrm{~min}$ at $94^{\circ} \mathrm{C}$ followed by 35 cycles of $30 \mathrm{~s}$ at $94^{\circ} \mathrm{C}$ for denaturing, $30 \mathrm{~s}$ at $60^{\circ} \mathrm{C}$ for annealing and a $30 \mathrm{~s}$ extension at $72^{\circ} \mathrm{C}$ with a final 5 min extension at $72^{\circ} \mathrm{C}$. Reactions containing the 2880 /B primers were amplified following the same procedure, except for an annealing temperature of $62^{\circ} \mathrm{C}$. The amplified fragments were cycle-sequenced in a 3130 Genetic Analyzer (Applied Biosystems) according to the manufacturer's specifications. Both strands of individual DNA fragments were sequenced to confirm ambiguous base calls. The sequences were merged using BioEdit (Hall 1999). To evaluate the phylogenetic signal of the 18S rRNA gene, sequences were compared with a $465 \mathrm{bp}$ sequence from Distoichometra bufonis (GenBank accession Z98377), a closely-related parasite of bufonids.

Ethics - The present study was approved by the Animal Research Ethics Committee of the Federal University of Pará (UFPA) through authorisation CEPAEUFPA: BIO010-10.

\section{RESULTS}

Twelve of the 20 R. marina specimens were infected with cestodes (a prevalence of $60 \%$ ) with five to 160 parasites per host.

\section{Lanfrediella gen. nov.} (Figs 1-33)

Diagnosis - Strobila apolytic becoming thinner in the terminal portion. Segments numerous, acraspedote, with external segmentation apparent in gravid and pregravid segments. Scolex with four suckers, simple, unarmed. Large ventral osmoregulatory canals. Double reproductive structures, including the following: bilateral genital atrium, two compact medullary dorsal testes, two lateral piriform cirrus pouches, two ovaries and two vitelline glands. Genital atrium lightly muscular. Cirri pouches thin not divided by a septum. Cirri with terminal spines. Vas deferens arise from testis loops twice, enters in medially to the cirrus pouch. External seminal vesicle absent. Paruterine organs paired. Two paruterine capsules, united basally, not surrounded by an outer envelope structure. Eggs with three membranes.

Etymology - The genus has been named after the late Reinalda M Lanfredi, PhD, in recognition of her valuable contributions to Brazilian helminthology and helminth systematics.

\section{Emended key to the genera of the Nematotaeniidae Lühe, 1910.}

1. Single group of reproductive organs ( 1 testis, 1 cirrus, 1 ovary and 1 vitelline gland) ...................... 3

2. Double group of reproductive organs ( 2 testes, 2 cirri, 2 ovaries and 2 vitelline glands) ...... Lanfrediella

3a. Two paruterine capsules or organs per segment ... 4

$3 b$. More than two paruterine capsules or organs per segment ............................................. 5

4a. Paruterine capsules surrounded by a second envelope ................................. Bitegmen Jones, 1987

4b. Paruterine capsules not surrounded by a second envelope ..................... Cylindrotaenia Jewell, 1916

5a. Paruterine capsules in row of two-six pairs of organs; four-12 paruterine capsules clustered in the posterior half of the segment ... Distoichometra Dickey, 1921

$5 b$. Paruterine organs not paired; five- 150 paruterine capsules or paruterine organs distributed randomly throughout the segment ......... Nematotaenia Lühe, 1899

\section{Lanfrediella amphicirrus gen. nov. sp. nov.} (Figs 1-33)

Description - Body elongated, $70 \mathrm{~mm} \pm 1.75$ (4.0-9.0) $(\mathrm{n}=20)$ long, scolex $541.46 \pm 100.70(373.33-706.67)$ in diameter, four oval acetabula, with no rostelum or apical organ. Suckers $151.10 \pm 16.31(128.67-183.00) \times$ $110.94 \pm 6.81$ (99.33-122.00) (Fig. 1); excretory canal ventral, $19.45 \pm 3.63(13.30-26.60)$ in diameter; mature segments $38.66 \pm 2.98(33.00-44.00) \times 333.83 \pm$ 10.14 (322.66-354.00); testes oval, $88.12 \pm 27.15$ (84.40$116.00) \times 31.52 \pm 4.17(25.90-38.90)$ (Figs 2-4); two 
thin-walled piriform, cirrus pouches, not divided by a septum, $40.05 \pm 1.50(36.84-41.57) \times 18.00 \pm 1.05(15.78-$ 19.47) (Figs 4, 5, 11-13); genital atrium lightly muscular, cirri straight, with terminal spines, $16.54 \pm 0.97$ (15.52-18.15) in length (Figs 24, 26, 27); two ovaries, spherical to oval, situated in the middle of the segment, $48.24 \pm 4.56(38.90-55.19) \times 38.47 \pm 6.30(30.51-50.00)$; two vitelline glands, oval, dorsolateral to the ovaries, $30.38 \pm 4.74$ (24.00-38.90) in diameter (Fig. 11); uterus dorsal or dorsolateral to the ovaries (Figs 4, 5, 11); pregravid segments $80.76 \pm 8.42(76.13-98.73) \times 853.41$ \pm 36.63 (789.42-894.73); paruterine complex $96.05 \pm$ $15.76(65.78-110.52) \times 34.29 \pm 5.79(28.31-47.36)$; gravid segments $259.67 \pm 65.08(191.56-374.68) \times 251.95 \pm$ 63.16 (200.00-388.96); two paruterine capsules, oval to spherical, $67.20 \pm 8.29(51.95-77.92) \times 34.29 \pm 5.79$ (28.31-47.36) (Figs 6-9); seven-10 oncospheres per capsule and 15-20 per segment; oncospheres with an oval outer envelope $30.15 \pm 3.18(26.31-33.94) \times 16.45 \pm 1.61$ (13.94-18.68), embryophore $18.83 \pm 5.88$ (17.30-22.36) $\times 13.73 \pm 1.73(12.76-15.52)$ and internal hooks, $7.85 \pm$ 1.07 (6.57-9.89) in length (Fig. 10).

The arrangement of the cirrus pouches was reconstructed from the 116 serial longitudinal dorsoventral sections of mature strobila segments. This 3D reconstruction revealed the equidistant distribution of the cirrus pouches that line each lateral margin of the mature segment of the strobila, between opposing pouches. This reconstruction confirms the presence of two sets of reproductive structures in each proglottid (Figs 14, 15).
1

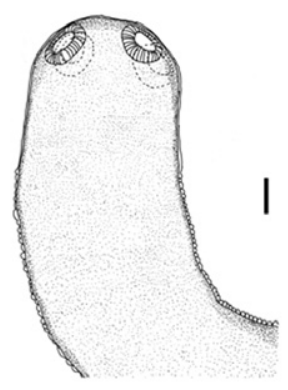

2

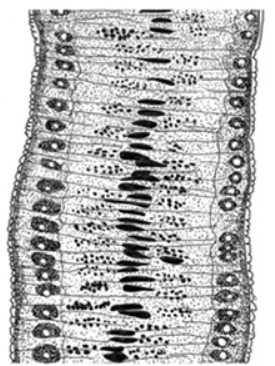

3

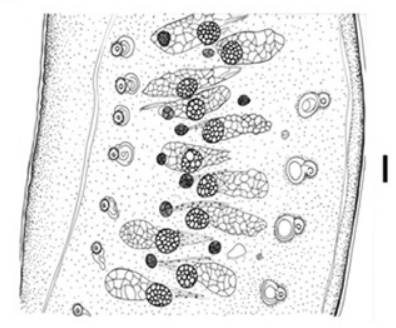

5

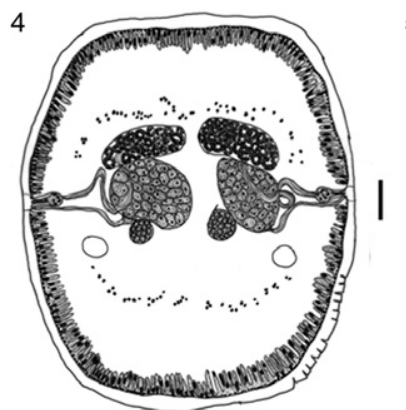

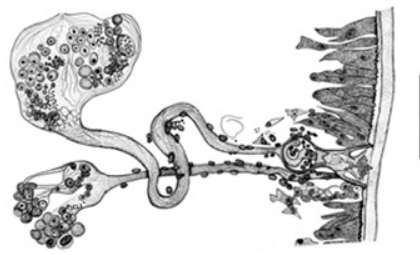

6

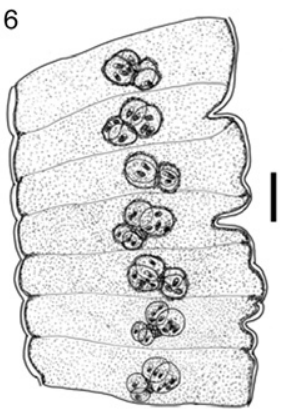

7

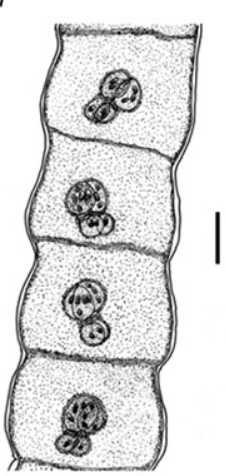

8

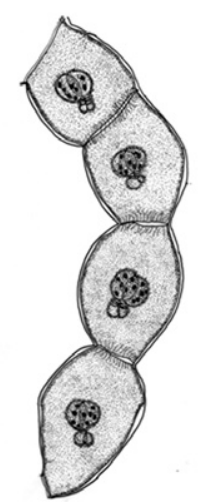

9

10

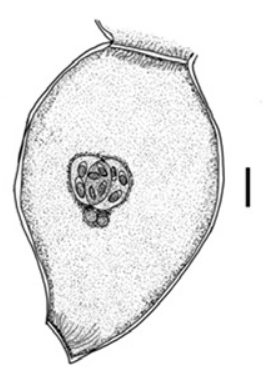

Figs 1-10: light microscopy of Lanfrediella amphicirrus gen. nov. sp. nov. 1: dorsoventral view of the scolex $($ Bar $=100 \mu \mathrm{m}) ; 2$ immature segments in a dorsoventral view $(B a r=50 \mu \mathrm{m})$; 3: mature segments $(B a r=50 \mu \mathrm{m})$; 4: cross section of mature segment showing two groups of reproductive organs and two cirrus pouches $(B a r=50 \mu \mathrm{m}) ; 5$ : reconstruction of a cirrus pouch with cirri showing the genital atrium, deferent channel and vaginal channel $(\mathrm{Bar}=50 \mu \mathrm{m}) ; 6$ : pregravid strobila segments showing the initial region of segmentation $(\mathrm{Bar}=100 \mu \mathrm{m}) ;$ : gravid segments showing the maturation of the paruterine capsules and visible segmentation $(B a r=100 \mu \mathrm{m})$; 8: posterior extremity showing gravid segments $(\mathrm{Bar}=100 \mu \mathrm{m}) ; 9$ : detail of a gravid segment where it is possible to observe two paruterine capsules per segment $(\mathrm{Bar}=50 \mu \mathrm{m}) ; 10$ : details of eggs showing the outer envelope, embriophore, and the oncosphere $(\mathrm{Bar}=30 \mu \mathrm{m})$. 
Type host - R. marina (Linnaeus, 1758) (Amphibia: Bufonidae), Cane Toad, Giant Toad.

Site of infection - Small intestine.

Type-locality - Belém, PA ( $\left.01^{\circ} 28^{\prime} 03^{\prime \prime} \mathrm{S} 48^{\circ} 20^{\prime} 18^{\prime \prime} \mathrm{W}\right)$.

Type data and depository - Holotype, deposited in the Helminthological Collection of the Oswaldo Cruz Institute (CHIOC) of the Oswaldo Cruz Foundation in Rio de Janeiro, Brazil, under catalogues CHIOC 37314a (holotype) and CHIOC 37314b, 35706 (paratype).

Molecular data - A partial sequence (1,253 nucleotides) of the 18S rRNA gene was obtained from L. amphicirrus gen. nov. sp. nov. and added to GenBank under accession HM185494. A comparison with D. bufonis identified a number of sites with potential for phylogenetic differentiation, including 18 substitutions and 15 indels, restricted to the 5 ' half of the alignment (not shown).

SEM of L. amphicirrus gen. nov. sp. nov. (Figs 16-26, 28-33) - SEM revealed that the scolex has simple suckers and no apical organ (Figs 16-19). The microtriches observed throughout the surface of the parasite are delicate, very short and filiform (Figs 20-22). The body presents distinct segmentation only in its most posterior portion. Two genital pores were observed in the mature segments
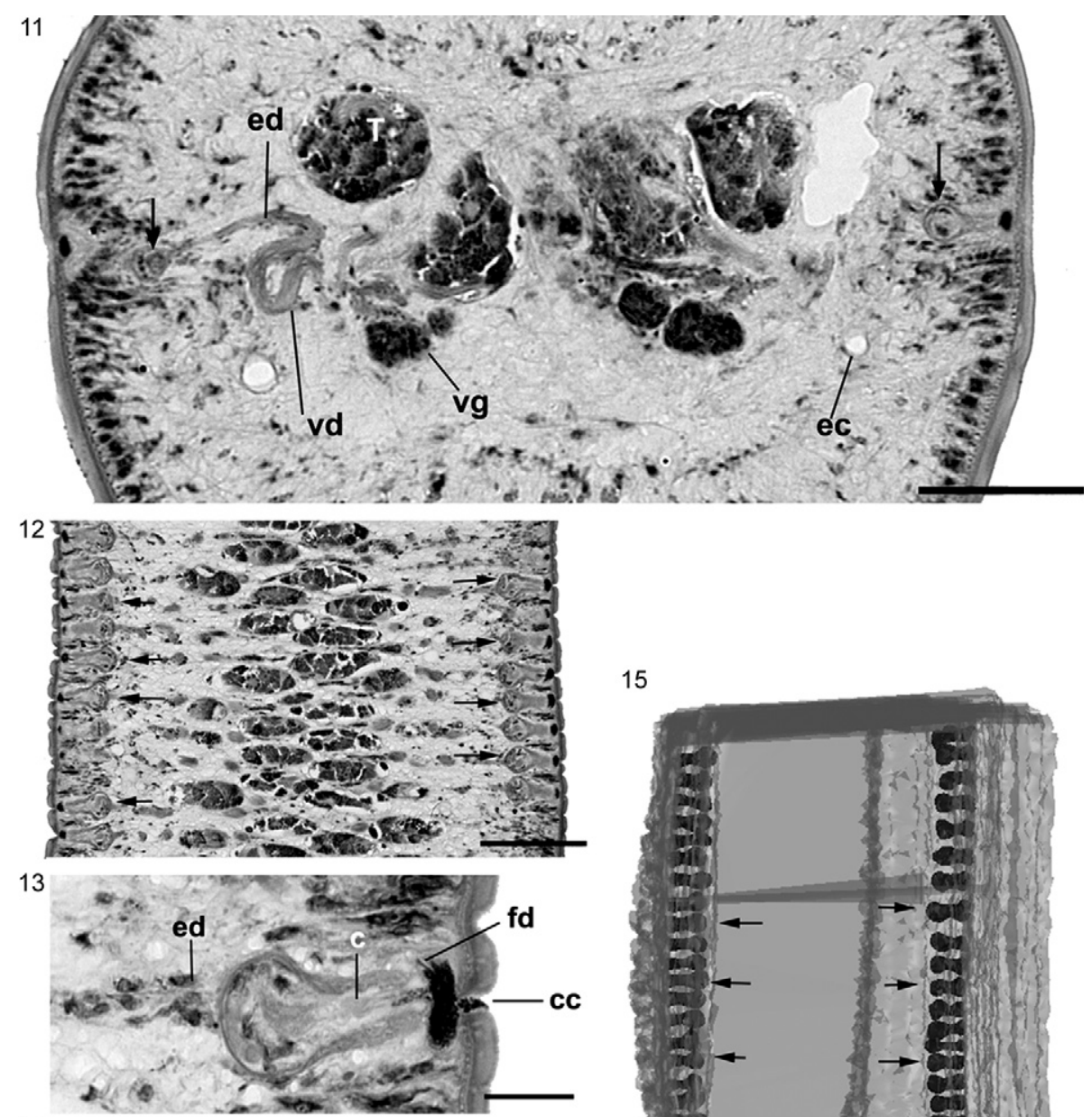

14
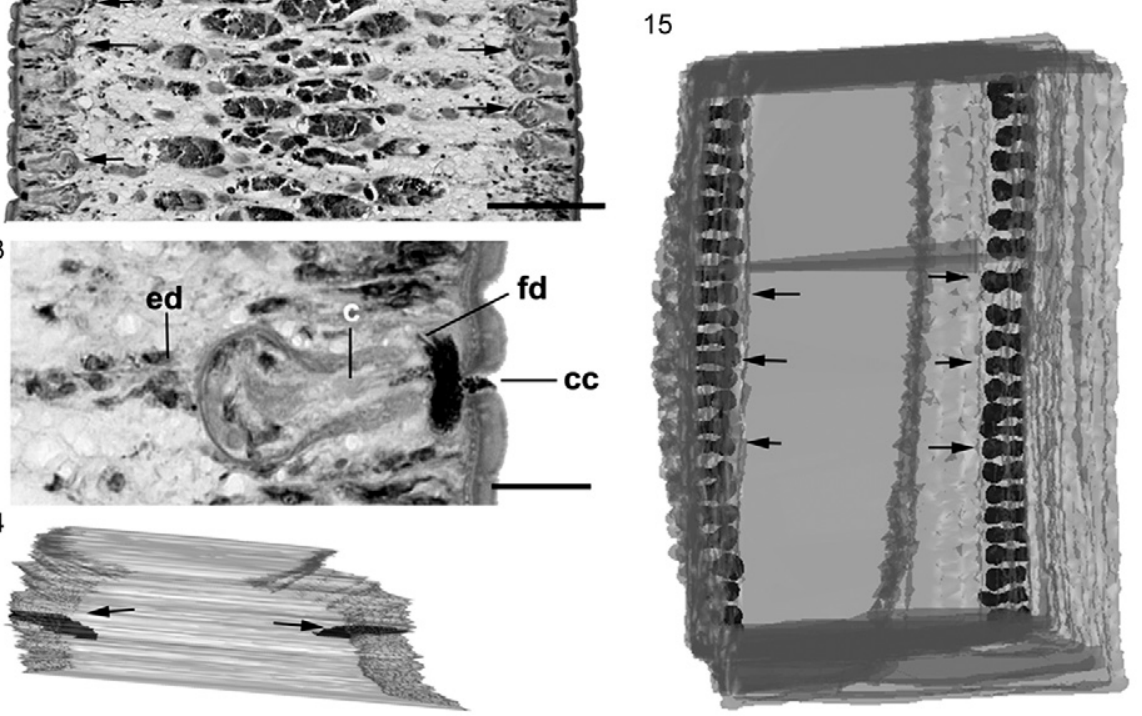

Figs 11-15: longitudinal and cross-sections of mature segments embedded in Historesin and three-dimensional (3D) reconstruction based on serial longitudinal sections of a strobila segment. 11: cross-section of mature segments showing testis (T), ejaculatory ducts (ed), vitelline glands (vg), viteline duct (vd), excretory channels (ec) and two cirrus (c) pouches (arrows) (Bar = $100 \mu \mathrm{m})$; 12: longitudinal section of a strobila with mature segments showing the presence of two c pouches (arrows) in each lateral side of the strobila $(\mathrm{Bar}=100 \mu \mathrm{m}) ; 13$ : detail of a c pouch in a longitudinal section of mature segments in which it is possible to observe the insertion of ed, c, female duct (fd) and the copulatory channel $(\mathrm{cc})(\mathrm{Bar}=100 \mu \mathrm{m})$; 14: superior view of in the transversal axis of 3D reconstruction where is possible to observe the internal position of two lateral rows of c pouches (arrows); 15: dorsoventral view in 3D reconstruction showing the position of c pouches (arrows) in each lateral margin of the strobila. 
(Figs 23-25). Some mature segments have partially extroverted, conical cirri with spine-like structures located distally (Figs 24, 26, 28). Genital pores could not be observed in the gravid segments (Figs 30-33).

Host-parasite data - Prevalence: $45 \%$.

Etymology - The species name is derived from the Greek prefix amphi-, meaning both, and thus refers to the double cirri and other reproductive structures.

\section{DISCUSSION}

The new genus Lanfrediella was allocated to the Nematotaeniidae family due to the presence of diagnostic morphological traits described for this family by Jewell (1916), Hsü (1935), Douglas (1958), Jones (1987) and Khalil et al. (1994). These traits include few testes per segment (2 or rarely 3 ), a cylindrical form, acraspedote segments with segmentation evident only in the posterior region of the body, the presence of conical paruterine organs immediately adjacent to the uterus, a distinct pattern of paruterine capsules (which are thin-walled that bear eggs formation developing at the anterior surface of uterus) and cylindrical strobila. All nematotaeniids are found in amphibian and reptile hosts.

Khalil et al. (1994) proposed a key to the family Nematotaeniidae that uses characteristics that are visible in the gravid and pregravid segments to distinguish the genera Nematotaenia, Cylindrotaenia, Distoichometra and Bitegmen. These genera can be differentiated primarily by the number and arrangement of the paruterine organs. Lanfrediella gen. nov. can be differentiated easily from Nematotaenia and Distoichometra. While the
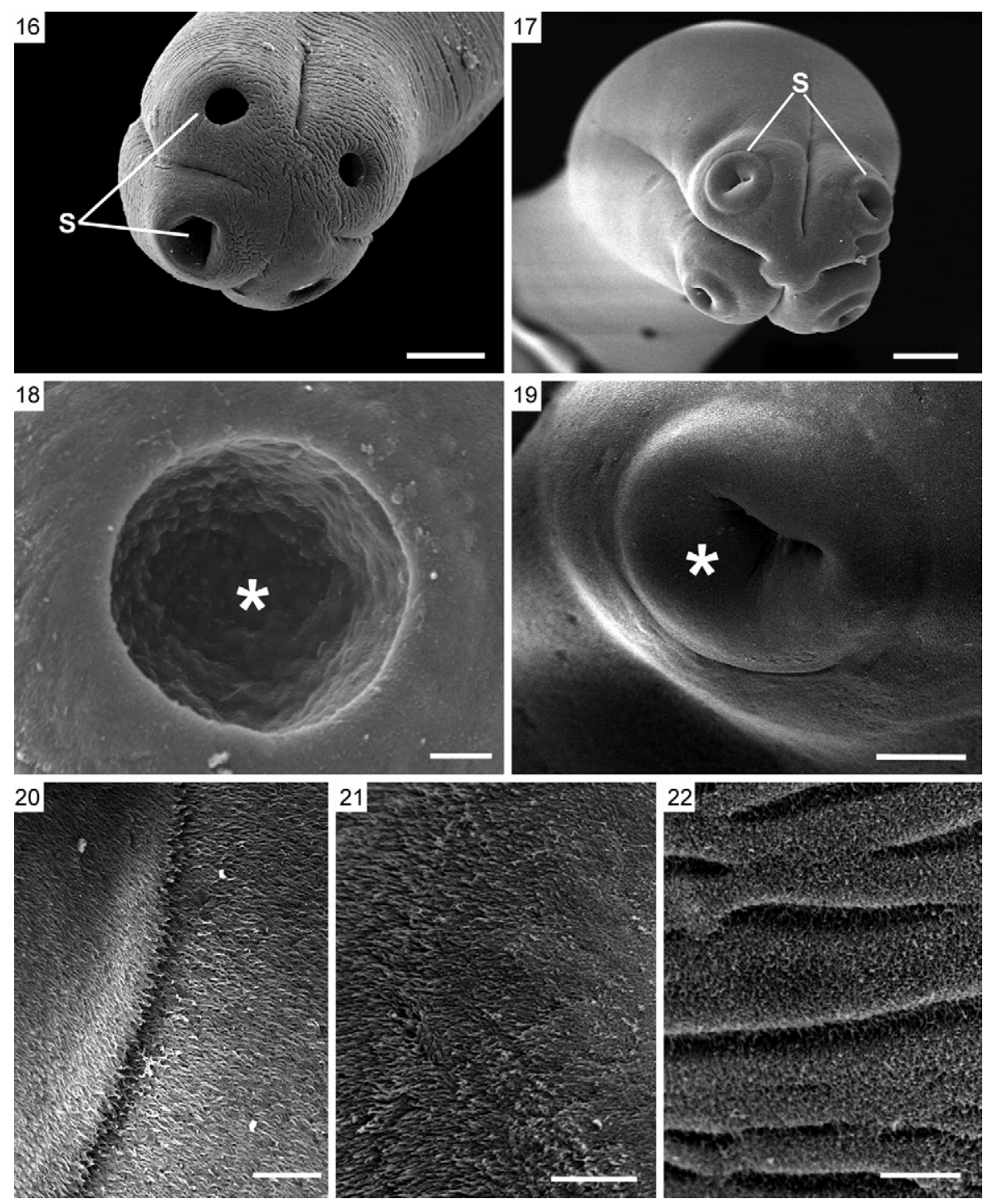

Figs 16-22: scanning electron microscopy of Lanfrediella amphicirrus gen. nov. sp. nov. 16: general view of relaxed scolex showing the suckers $(\mathrm{S})$, absence of a rosteolum or apical organ $(\mathrm{Bar}=100 \mu \mathrm{m})$; 17: overall view of contracted scolex showing morphology of $\mathrm{S}$ in this moment $(B a r=100 \mu \mathrm{m}) ; 18$ : internal details of $\mathrm{S}$ (asterisk) in contracted scolex. Note the absence of spines or any other structures $(\mathrm{Bar}=10 \mu \mathrm{m}) ; 19$ : internal details of $\mathrm{S}$ (asterisk) in contracted scolex $(\mathrm{Bar}=100 \mu \mathrm{m}) ; 20$ : details of the microtriches close to border of $\mathrm{S}(\mathrm{Bar}=10 \mu \mathrm{m}) ; 21$ : details of microtriches in immature segments $(\mathrm{Bar}=10 \mu \mathrm{m}) ; 22$ : details of microtriches in mature segments $(\mathrm{Bar}=10 \mu \mathrm{m})$. 
new genus has only two paruterine capsules per gravid segment, Nematotaenia and Distoichometra have more than two capsules (Hsü 1935, Douglas 1958, Yamaguti 1959, Jones 1987, Khalil et al. 1994).

Bitegmen has only two paruterine capsules per segment, although each capsule is surrounded by an outer enveloping structure (Jones 1987, Khalil et al. 1994). The sperm duct does not loop within the cirrus pouch, the anterior portion of the genital atrium is surrounded by muscular tissue and a septum separates the distal portions of the cirrus pouch. In contrast, mature and gravid segments of Lanfrediella gen. nov. lack all of these traits.

According to Jones (1987) and Khalil et al. (1994), the mature segments of Cylindrotaenia (Jewell 1916) have two paired paruterine organs that are united basally and gravid segments with two paruterine capsules, a feature also seen in Lanfrediella gen. nov. However, the new genus differs conspicuously from Cylindrotaenia in that it has two of each reproductive structure (cirri, cirrus pouches, testes, ovaries and vitelline glands) in each segment.

L. amphicirrus gen. nov. sp. nov. is the first cyclophyllidean tapeworm to be found in Amazonian R. marina. Specimens of Cylindrotaenia americana have been collected from Rhinella toads in southern Brazil, including the states of Paraná (Stumpf 1982), São Paulo (Jones 1987) and Rio Grande do Sul (Santos \& Amato 2010).

The comparison of Lanfrediella gen. nov. with other nematotaeniid genera using classical techniques was
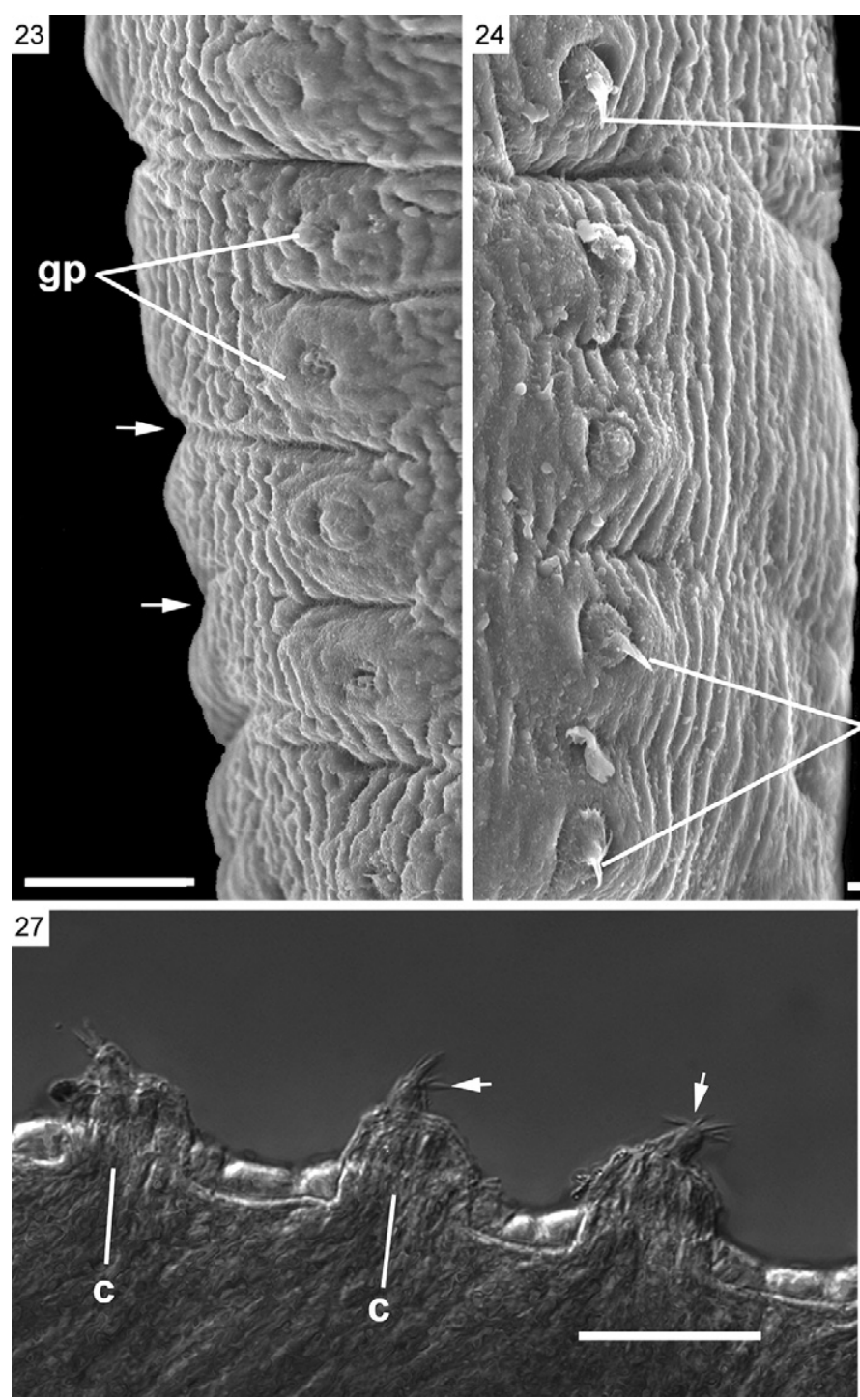
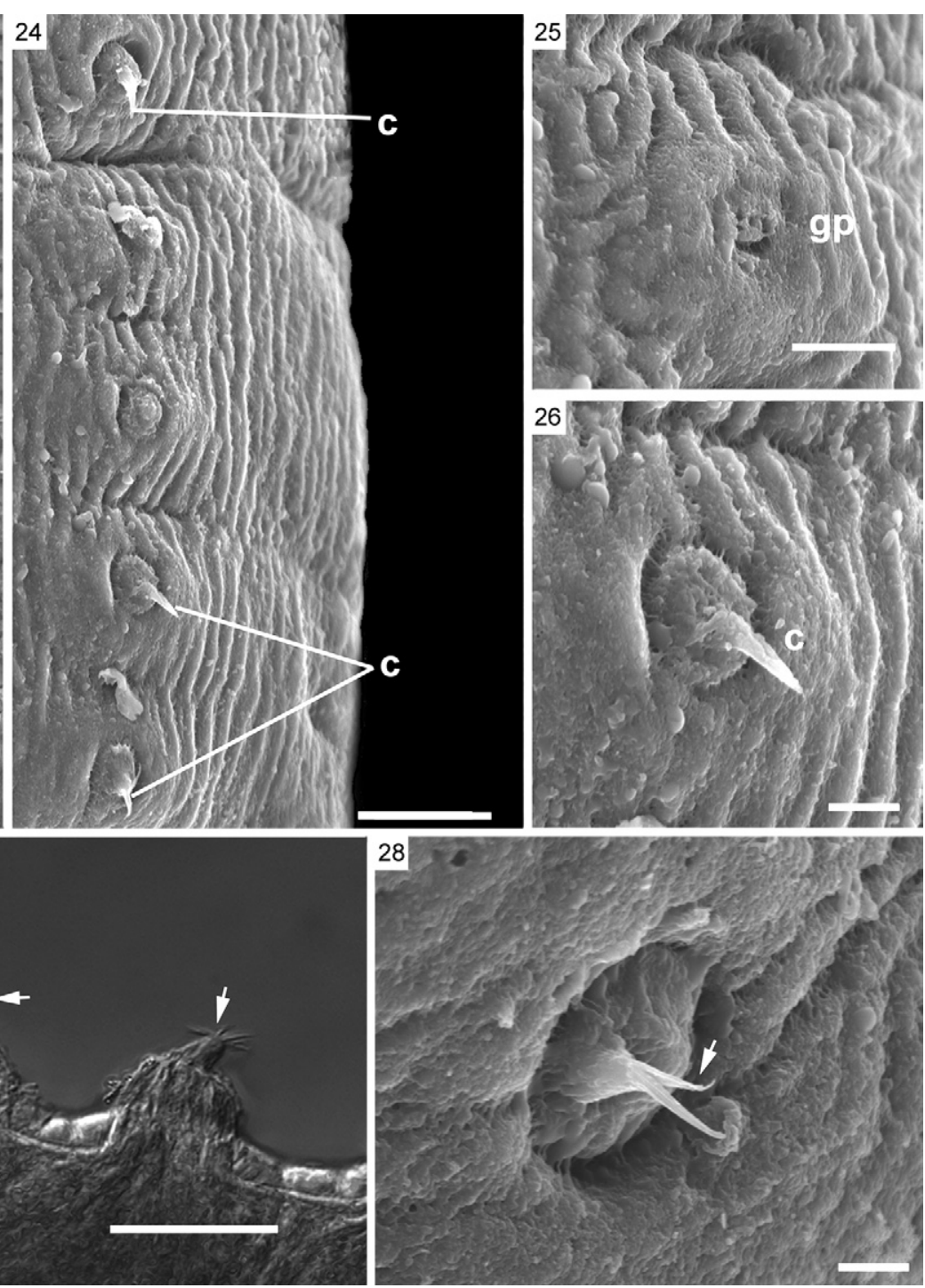

Figs 23-28: scanning electron microscopy of mature segments and differential interference contrast (DIC) of mature segments of Lanfrediella amphicirrus gen. nov. sp. nov. 23: lateral view of a mature segment showing the segmentation (arrow) and genital pores $(\mathrm{gp})(\mathrm{Bar}=26 \mu \mathrm{m}) ; 24$ : view of the opposite side of the segment in Fig. 23 showing the gp and a partly extroverted (C) $(\mathrm{Bar}=20 \mu \mathrm{m}) ; 25$ : view of the region of the gp region observed in Fig. 23 (Bar $=10 \mu \mathrm{m})$; 26: details of the cirrus (c) located in the mature segment observed in Fig. $24(\mathrm{Bar}=5 \mu \mathrm{m}) ; 27$ : image of DIC of mature segments with the best-adjusted focus obtained using the CombineZP software showing c extroverted with many spines (arrows) $(\mathrm{Bar}=100 \mu \mathrm{m}) ; 28$ : partially extroverted $\mathrm{c}(\mathrm{Bar}=3 \mu \mathrm{m})$. 
hampered by the difficulties of observing the internal organs as described by Jones (1987), showing the necessity for the use of different tools to improve the classification

This is the first study of cestodes that used Historesin, which simplified the diagnosis and observation of internal structures, such as testes, ovaries, vitelline glands, sperm ducts and cirrus pouches. Based on these results, this technique is recommended for use in future studies of these organisms. Embedding in Historesin preserved the tegument and other structures, which become retracted in specimens embedded in paraffin.

Reconstruction of complex internal structures from serial histological sections is a complex and time-consuming task (Fiala 2005); however, in the present study, $3 \mathrm{D}$ reconstruction facilitated the visualisation of these structures in the helminths, which are difficult to ob- serve using standard techniques. As the segmentation of the body is difficult to observe in mature segments, this technique may become an extremely useful tool for the analysis of internal structures in nematotaeniids and the development of a more systematic approach to the taxonomy of these helminths.

This is also the first study of a nematotaeniid parasite using SEM, which revealed morphological details of structures such as the scolex, suckers, genital pores, cirri, microtriches and segmentation of the strobila, which are representative of the genus. The use of SEM improved upon the results obtained with light microscopy in these analyses. The use of SEM also permitted the detection of two genital pores per segment and thus appears to be a valuable tool for analysing the external morphology of cestodes.
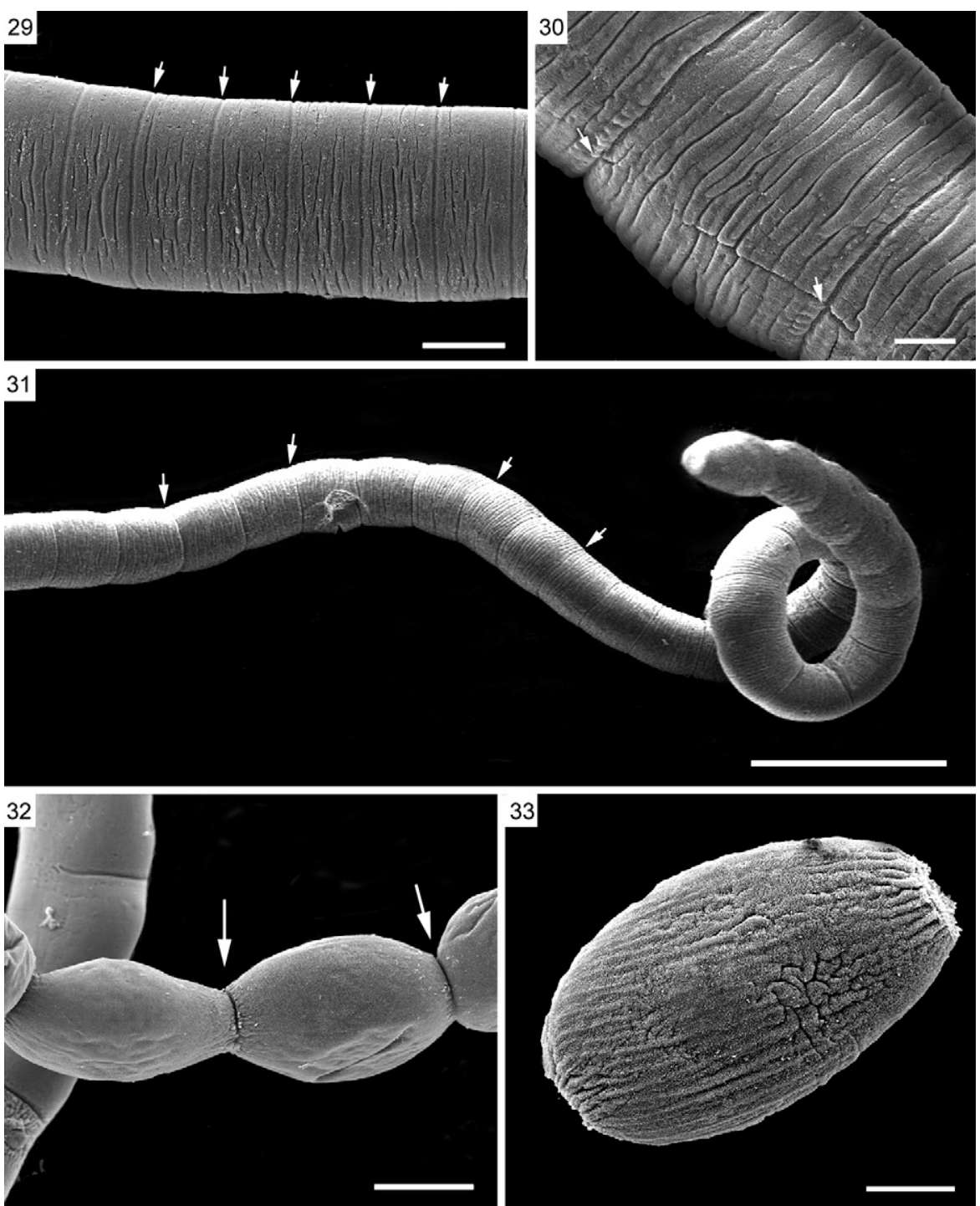

Figs 29-33: scanning electron microscopy of mature and gravid segments of Lanfrediella amphicirrus gen. nov. sp. nov. 29: mature segments of parasite showing the segmentation (arrows) $(B a r=100 \mu \mathrm{m})$; 30: gravid segment view in strobila where is possible to observe the segmentation (arrows) $(B a r=100 \mu \mathrm{m}) ; 31$ : posterior end of a strobila showing the segmentation of gravid segments (arrows) $(\mathrm{Bar}=400 \mu \mathrm{m}) ; 32$ : end portion of the parasite showing the constrictions between gravid segments (arrows) $(\mathrm{Bar}=100 \mu \mathrm{m})$; 33: isolated gravid segment. Note the elliptical morphology, characteristic of this stage, and the absence of genital pores $(\mathrm{Bar}=50 \mu \mathrm{m})$. 
The molecular database for cestodes is still very limited and most of the nucleotide sequences available in GenBank as of December 2010 were from species of medical or veterinary interest. The only available sequences from nematotaeniids are short fragments of the 18S rRNA gene of D. bufonis obtained by Mariaux (1998). Our molecular analysis results represent an important complement to the data available for the Nematotaeniidae, which will be valuable for future phylogenetic analyses and species classifications through the addition of new taxa and genes.

\section{ACKNOWLEDGEMENTS}

To late Reinalda Marisa Lanfredi (in memoriam) and Djane Clarys Baia da Silva, for their valuable assistance, to Dr Edilson Matos (Laboratório de Pesquisa Carlos Azevedo/ ISPA/UFRA), Dr Hilton Tulio Costi (Laboratory of Scanning Electron Microscopy/MPEG), for his technical support with the SEM analyses, to Dr Wanderley de Souza, head of the Hertha Meyer Cell Ultrastructure Laboratory of UFRJ, for access to SEM, to Dr Stephen Ferrari, for English revision, and the anonymous referees, for valuable comments and suggestions.

\section{REFERENCES}

Barton DP 1997. Introduced animals and their parasites: the cane toad Bufo marinus in Australia. Aust J Ecol 29: 316-324.

Douglas LT 1958. The taxonomy of nematotaeniidae cestodes. J Parasitol 4: 261-273.

Espínola-Novelo JF, Guillén-Hernandez S 2008. Helminth parasites in Chaunus and Cranopis valliceps (Anura: Bufonidae) from Lagunas Yalahau, Yucatan, Mexico. J Parasitol 94: 672-674.

Espinoza-Jiménez A, Garcia-Sarabia L, Osorio-Sarabia D, LeónRègagnon V 2007. Checklist of helminth parasites of the cane toad Bufo marinus (Anura: Bufonidae) from Mexico. J Parasitol 93: 937-944.
Fiala JC 2005. Reconstruct: a free editor for serial section microscopy. J Microsc 218: 52-61.

Hall TA 1999. BioEdit: a user-friendly biological sequence alignment editor and analysis program for Windows 95/98/NT. Nucl Acids Symp Ser 41: 95-98.

Hsü HF 1935. Contributions à l'étude des cestodes de Chine. Pev $S$ Zoole 42: 447-570.

Jewell ME 1916. Cylindrotaenia americana nov. spec. from the cricket frog. J Parasitol 2: 186-196.

Jones MK 1987. A taxonomic revision of Nematotaeniidae Lühe, 1910 (Cestoda: Cyclophylidea). Syst Parasitol 10: 165-245.

Khalil LF, Jones MK, Bray RA 1994. Keys to the cestodes parasites of vertebrates, CAB International, St Albans, $751 \mathrm{pp}$.

Mariaux J 1998. A molecular phylogeny of the Eucestoda. J Parasitol 84: 114-124.

Santos JN, Giese EG, Maldonado Jr A, Lanfredi RM 2008. A new species of Oswaldocruzia (Molineidae: Nematoda) in Chaunus marinus (Amphibian: Bufonidae) (Linnaeus, 1758) from Brazil. J Parasitol 94: 264-268.

Santos JN, Melo FTV, Nascimento LCS, Nascimento DEB, Giese EG, Furtado AP 2011. Rhabdias paraensis sp. nov.: a parasite of the lungs of Rhinella marina (Amphibia: Bufonidae) from Brazilian Amazonia. Mem Inst Oswaldo Cruz 106: 433-440.

Santos VTG, Amato SB 2010. Helminth fauna of Rhinella fernandezae (Anura: Bufonidae) from the Rio Grande do Sul coastland, Brazil: analysis of the parasite community. J Parasitol 96: 823-826.

Skeriková A, Hypsa V, Scholz T 2001. Phylogenetic analysis of European species of Proteocephalus (Cestoda: Proteocephalidea): compatibility of molecular an morphological data and parasitehost coevolution. Int J Parasitol 31: 1121-1128.

Stumpf IVK 1982. Ciclo evolutivo de Cylindrotaenia americana Jewell, 1916 (Cyclophyllidea: Nematotaeniidae) em Bufo ictericus Spix, 1824. Acta Biol Paran 10/11: 31-39.

Yamaguti S 1959. Systema helminthum, vol. II. In The cestodes of vertebrates, Interscience Publishers, New York, p. 1665-1666. 